\title{
温度成層を考慮に入れを自然風現象の 風洞模型実験についで
}

\author{
井上栄 一 \\ （農業技術研究所 気象科）
}

On the Model Experiments in Wind Tunnel of Atmospheric Phenomena

Accompanied with Effects of the Thermal Stratification

E. INOUE

(Division of Meteorology, National Institute of Agricultural Sciences)

\section{1. ま えがき}

防風林や防風垣などの風洞模型実験では一般に強い風 の下に起る現象を対象とするから，気層の熱的な安定性 を考慮する必要がないるのと考学られている。しかし実 物の防風林などについての観測は必ずしも強風のもとに 行われるとは限らず，真夏の日中で弱い風の下に防風林 前後の風速分布の測定を行って, その防風林の防風効果 を求めたりすることも多い。このような場合には当然接 地気層は不安定な状態にあるものと考兄られ，そこで求 められた風速の低下現象を, 期待されるような強風下の 防風率として解釈することは許されない。即ち防風林な ぞの防風効果に対する気層安定度の影響が予めしらべら れなければならないことになる。

一方同じ林帯や垣根であつてもそれを防霜林としてそ の効果を期待する場合には，一般に冷却のはげしい夜間 であり, 風速も弱くて気層が極めて安定した状態の下に 起る現象が問題となる。このような現象は重要なるのと はみなされながらも, 観測が困難であつたり模型実験が 困難であつたりするため詳細な研究対象とはなり得なか つたようであり，断片的な観測が行われたに過ぎなかつ た。

著者（井上 1952）はこれまで自然風の中に起る各種の 現象が乱流拡散の考方方によつて解釈されるものとして 乱流拡散現象の相似法則をるつて風洞模型実験の相似法 則に代用することを提案し，

(I ) 乱れの強さの一致

(II) 乱流 Reynolds 数**の一致

を必要な条件として与皃た。この思想は谷（1958）によ り模型防風垣の風洞実験によつて検討され, 可成りの確 からしさをもつて有効であることが示された。しかし著

* 1958 年 11 月 12 日, 第 5 回「風に関するシンポジウム」 において発表

**これは最近「有効 Reynolds 数」とよばれ, 各種の空気 力学的現象に採用されるようになつた（今井 1958)。
者のこれまでの考方方の中には，気層の安定性の効果が 全く無視されていたので, この思想を気層安定度の如何 にかかわらず成立するょうな形態に拡張することが必要 になつて来た。また一方に䞑いて，谷（1958）がその必 要性を述べていたような，「底板を加熱又は冷却して熱 の境界層を作り」得るよらな風洞施設の完成も近づきつ つある。そこで著者はまず理論的に乱流拡散現象に対す る温度成層の効果を予測し，その現象の相似法則を提案 することにする。この提案が再び近い将来に扔いて実験 的に検証されることを著者は期待している。

\section{2. 温度成層のない接地気層内の 乱流拉散現象之相似条件}

接地気層の中に怙ける乱流払散現象が気流の乱流構造 によつて表わされることについてはすでに多くの研究が 発表されている（例觉ば 井上 1956）。一例として高さ Hの煙突から出る煙の垂直方向の拡散について考兄よ う。よくしられているようにこういう場合の拡散現象は Lagrange 相関係数 $R_{w}(\xi)$ と乱れの強さ(あるいは風の 息) $\left\langle w^{2}\right\rangle^{1 / 2} / U$ とによつて記述することが出来て, 拡散 する煙の垂直方向の幅 $\left\langle Z^{2}\right\rangle^{1 / 2}$ と煙突の出口から風下に 測られた距離 $x$ との関係は

$$
\left.\begin{array}{rl}
\left\langle Z^{2}\right\rangle & =2\left\langle w^{2}\right\rangle \int_{0}^{t} \int_{0}^{\eta} R_{w}(\xi) d \xi d \eta, \\
t & =x / U
\end{array}\right\}
$$

で表わされる (Taylor 1921)。著者（井上 1956）が先 に与えたように $R_{w}(\xi)$ として

$$
R_{w}(\xi)=\exp \left(-\xi / \tau_{w}\right)
$$

を採用すれば，幅 $\left\langle Z^{2}\right\rangle^{1 / 2}$ と操作時間 $t(=x / U)$ あるい は距離 $x$ との関係は

$$
\left\langle Z^{2}\right\rangle^{1 / 2}=\sqrt{2}\left\langle w^{2}\right\rangle^{1 / 2}\left\{\frac{t}{\tau_{w}}-1+\exp \left(-t / \tau_{w}\right)\right\}^{1 / 2}
$$

で与えられる。ここに $\tau_{w}$ は垂直連結乱子の寿命時間で あり, 気層安定度が中立状態にある場合には 


$$
\tau_{\imath v}=\frac{k H}{V_{*}}
$$

で表わされるものと考它られている。但し $V_{*}, k$ はそれ ぞれ摩擦速度, Kármán 常数を意味する。

(2.3) で与えられる煙の幅のひろがりは, 出口の極く 近傍（ $t \rightarrow 0$ 又は $x / U \rightarrow 0 ）$ と出口から十分に離れた場 所 $(t \rightarrow \infty$ 又は $x / U \rightarrow \infty)$ とで夫々次のよ5になること が導かれる：

( I ) $t \rightarrow 0$,

$$
\left\langle Z^{2}\right\rangle^{1 / 2}=\left\langle w^{2}\right\rangle^{1 / 2} t=\left\langle w^{2}\right\rangle^{1 / 2} \frac{x}{U}
$$

(II) $t \rightarrow \infty$,

$$
\begin{aligned}
\left\langle Z^{2}\right\rangle^{1 / 2} & =\sqrt{2}\left\langle w^{2}\right\rangle^{1 / 2} \tau_{w}\left(\frac{t}{\tau_{w}}-1\right)^{1 / 2} \\
& =\sqrt{2}\left\langle w^{2}\right\rangle^{1 / 2} \tau_{w}\left(\frac{x}{U \tau_{w}}-1\right)^{1 / 2}
\end{aligned}
$$

便宜上著者は前者を第 I 種桩散領域と名づけ, 後者を第 II種領域と名づけているが，上の二式より明らかなよう

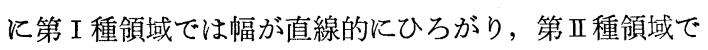
は放物線的にひろがる点に明らかなそれぞれの特徵が見 られる。第 I 種領域のひろがりの角度を $\theta_{Z}$ で特徵ずけ れば, (2.5) 式より

$$
\tan \theta_{z}=\frac{\left\langle Z^{2}\right\rangle^{1 / 2}}{x}=\frac{\left\langle w^{2}\right\rangle}{U}
$$

となり, $\theta_{Z}$ の大小がそのまま風の息 $\left\langle w^{2}\right\rangle^{1 / 2} / U$ の大小 を表わすこととなる。また第 I 種と第 II 種の両領域の移

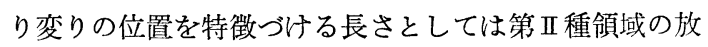
物線の頂点の位置を与える長さ

$$
L_{Z}=\tau_{w} U
$$

をとることは合理的であろう。このようにして拡散現象 の幾何学的形状を特徵づける量としては角度 $\theta_{Z}$ と長さ $L_{Z}$ とをとることが合理的となる。

さて中立的な気層安定度の状態にある接地気層では風 速の高度分布が対数法則

$$
U=\frac{V_{*}}{k} \ln \frac{Z}{Z_{0}}=5.75 \quad V_{*} \log \frac{Z}{Z_{0}}
$$

で表わされることはよく知られている。ここに $Z_{0}$ は地 表面の粗さを特徵づける長さであり, 便宜上地表面修正 量 $d$ の存在は無視出来るものと考兄られている。また風 速の垂直変動量 $\left\langle w^{2}\right\rangle^{1 / 2}$ は摩擦速度 $V_{*}$ に比例し,

$$
\left\langle w^{2}\right\rangle^{1 / 2} \approx V_{*}
$$

で与えられることが知られている（例えば井上・谷・今 井 1955)。従つて高さ $H$ の煙突より出る煙の拡散角度 $\theta_{Z}$ は (2.7) の関係より

$$
\begin{aligned}
\theta_{Z} & =\tan ^{-1} \frac{\left\langle w^{2}\right\rangle^{1 / 2}}{U} \approx \tan ^{-1} \frac{V_{*}}{U} \\
& =\tan ^{-1} \frac{k}{\ln \frac{H}{Z_{0}}}
\end{aligned}
$$

で5觉られることとなり，㑇度 $\theta_{z}$ は煙突の高さ $H$ と地 表䤄の粗さを特徵つける产さ $Z_{0}$ との此 $\left(H / Z_{0}\right)$ によつ て決定されることがわかる。従つて一定の $H$ に対して は $Z_{0}$ が大きくなればなるほど，つまり粗さが著しいほ ぞ $\theta_{Z}$ は大きくなる。また同じような対数法則の適用さ れる二つの乱流場があるとして, それぞれの中にある $H_{1}$ 拉よび $H_{2}$ という高さの煙突から出る煙の拡散を考える とさには，両者の地表面の粗さを特徵づける長さ $Z_{01}$ 拈 よび $Z_{02}$ が

$$
\frac{H_{1}}{Z_{01}}=\frac{H_{2}}{Z_{02}}
$$

で示される関係を満足させる時に両者の拡散角度が一致 することになる。一方両者の拡散領域が幾何学的に相似 であるためには (2.8) で与えられる長さ $L_{Z}$ と煙突の高 さ $H$ との比も一致していなければならないが，(2.8) お よび (2.4) 式を考虑に入れればこの比 $\left(L_{Z} / H\right)$ も

$$
\frac{L_{Z}}{H}=\frac{k H}{V_{*}} \cdot U \cdot \frac{1}{H}=\frac{k U}{V_{*}}=\ln \frac{H}{Z_{0}}
$$

で示されるように $\left(H / Z_{0}\right)$ によつて決定されることがわ かり，角度を一致させるための条件 (2.12) と全く同一 の条件によつて一致させられることになる。

結局中立状態の安定度条件のもとでは,

（a）二つの乱流場の速度分布が同様な対数法則で表 わされるような状態にあり，

(b) 特徵的な高さ $H$ と地表面の粗さを特徽づける 高さ $Z_{0}$ との比 $\left(H / Z_{0}\right)$ が一致しているならば, それら二つの乱流場に招ける乱流拡散現象が幾何学的に 相似となることになる。これら二つの条件はまた見方を 変えれば,

$\left(\mathrm{a}^{\prime}\right)$ 乱れの強さ $\left(V_{*} / U\right)$ の一致

$\left(\mathrm{b}^{\prime}\right)$ 乱流 Reynolds 数 $\left(R_{K}=U H / K_{Z}=\left(U / V_{*}\right)(H /\right.$ $k H)$ ) の一致

を求めた著者らの以前の結果 (井上 1952 , 谷 1958 , 根 本 1958）と全く一致するものであることが容易に判る。

速度についての条件と長さあるいは寸法についての条 件の二つから, 自然に時間についての条件が生じて来る。 この場合には特徵的な時間として (2.4)で与兄られた寿 命時間 $\tau w$ をとることは極めて自然なことであろう。そ こで二つの現象の間の特徵的時間量の比として

$$
\frac{\tau_{w 1}}{\tau_{w 2}}=\frac{H_{1} / V_{* 1}}{H_{2} / V_{* 2}}=\frac{H_{1}}{H_{2}} \cdot \frac{U_{2}}{U_{1}}
$$

が求められる。より複雑な同種の条件は同じ著者によつ てすでに与えられているが (Inoue 1951)，条件 (2.14) はその中の特別な場合に相当している。時間縮率 ( $\left.\boldsymbol{\tau}_{w 1}\right)$ $\tau w 2)$ は寸法縮率 $\left(H_{1} / H_{2}\right)$ と速度縮率の逆数 $\left(U_{2} / U_{1}\right)$ と の積として与えられているが，一般に速度縮率は 1 から 
甚しく離れることのないのが普通であるため，従来は経 験的に時間縮率と寸法縮摔とが一致するとい5見方すな されて来たようである。例えば工場の煙突より出る煙に よる大気污染を風洞実験的にしらべるために Sherlock 及び Lesher (1954) は工場の (1/300) 模型を作り, 風 洞に於て $1 \mathrm{sec}$ の間に起る現象が実物についての $300 \mathrm{sec}$ (5 min) 間に起る現象に対応すると述べているのもとの 一例とみなされるが，正確には実際の風速と風洞風速と を一致させなければ彼等の記述は誤りを犯すことになろ う。しかし幸なことに自然風速と風洞実験風速とはほぼ 同じ程度に選ばれることが多いため, 経験的にはSherlock-Lesher の記述でる不都合は生じないことになるも のとみなされる。

\section{3. 相似条件に対する気層安定度の 効 果}

接地気層に拈ける温度成層の状態が中立あるいは断熱 状態として知られているものから離れるにつれて, 前節 の考察の基礎となつている風速高度分布の対数法則が次 第に適用されなくなるため, そのような状態の下に起る 拡散現象についての相似条件としては前節に得られたも のより若干複雑なものが要求されるということは容易に 予想される。

まず風速高度分布について言えば, 安定度の効果が著 しくなるにつれて対数法則からのはずれが著しくなつて 来ることが知られるようになり，その分布法則が

$$
\frac{U}{V_{*}}=5.75 \log \frac{Z}{Z_{0}}+\alpha \frac{\left(Z-Z_{0}\right)}{L},
$$

あるいは右辺第 2 項の $Z_{0}$ を $Z$ に比べて無視出来るもの として

$$
\frac{U}{V_{*}}=5.75 \log \frac{Z}{Z_{0}}+\alpha \frac{Z}{L}
$$

という形のいわゆる (対数十直線) 法則で与えられるこ とが最近多くの人々によつて求められるようになつた (例えば Sheppard 1958)。ただし $L$ は安定度の程度を 表わす量で次のように定義され，長さの次元を持つてい る :

$$
L=-\frac{V_{*}{ }^{3}}{k \frac{g}{\Theta_{0}} \frac{q}{C_{p} \rho}},
$$

$g=$ 重力加速度

$\Theta_{0}=$ 平均温度 $\left({ }^{\circ} \mathrm{K}\right)$

$q=$ 輸送熱量, 上向きを正にとる。つまり不安 定状態では正, 安定状態では負。

$C_{p}=$ 空気の定圧比熱

$\rho=$ 空気密度

この長さはまだはつきりした名前をつけられていないが
藷者は仮りに「安定度の長さ (stability length)」と呼 ぶことにする。また $\alpha は$ 経験的常数であつてまだその確 定的な数值は得られていないけれどもこれまでの之しい 資料からは 0.6〜2 の間にあるものとみなされるようで ある(井上 1957)。

(3.2) 式を書き直せば

$$
\frac{V_{*}}{U}=\frac{1}{5.75 \log \frac{Z}{Z_{0}}+\alpha \frac{Z}{L}}
$$

となり, 断熱状態の場合と同様に $\left(V_{*} / U\right)$ が乱れの強さ を表わするのとするならば, 乱れの強さは地表面の粗さ の影響を表わす $\left(Z / Z_{0}\right)$ と安定度の影響を表わす $(Z \mid L)$ との二つの項の各々に関係することとなる。従つてこの 場合には高さ $H$ の煙突から出る煙の拡散角度 $\theta_{Z}$ は

$$
\begin{aligned}
\theta_{Z} & =\tan ^{-1} \frac{\langle w\rangle^{1 / 2}}{U} \approx \tan ^{-1} \frac{V_{*}}{U} \\
& =\tan ^{-1} \frac{1}{5.75 \log \frac{H}{Z_{0}}+\alpha \frac{H}{L}}
\end{aligned}
$$

によつて表わされることが出来, 角度 $\theta_{Z}$ は $\left(H / Z_{0}\right)$ の みならず $(H / L)$ によつてる左右されることになる。後 者の $(H / L)$ は不安定状態では負, 安定状態では正の值 を持つから， $\theta_{Z}$ は不安定になるほど大きく, 安定になる ほど小さくなることが容易に判る。先に前節では $Z_{0}$ の 大きいほど, つまり地表面が粗いほど煙の拡がる角度が 大きくなることを述べたが，気層が不安定になるにつれ ても $\theta z$ は大きくなるから，一見した所角度を増大させ るという効果だけから言えば地表面が粗くなるというこ とと気層が不安定になるということは同様な効果を持つ ものと言える。

さて二つの乱流場を考えて，(2.12)で与えられた地表 面の粗さについての条件の他に

$$
\frac{H_{1}}{L_{1}}=\frac{H_{2}}{L_{2}}
$$

そいら条件が満足されるならば，(3.5) から明らかなよ うに両者に拉ける拡散角度は一致することになる。つま り安定度の効果によつて拡散角度の相似条件が二つ必要 となつたわけである。

一方払散領域の幾何学的相似のも

$$
\frac{U \tau_{w}}{H}=\frac{U}{V_{*}}=5.75 \log \frac{H}{Z_{0}}+\alpha \frac{H}{L}
$$

で与えられ，ここでも $\left(H / Z_{0}\right)$ と $(H / L)$ が同時に等し くなければならないことになる。

粗さの効果を表わす項 $\left(H \mid Z_{0}\right)$ を相似にすることは, 断熱状態の場合と同様に模型の地表面の粗さを適当に作 ることによつて達成されるが，問題は安定度の効果を表 
わす項 $(H / L)$ を相似にさせることにある。(3.3) で定 義された $L$ の量を使つて (3.6) を書き直せば

$$
\frac{k \frac{g}{\Theta_{0}} \cdot \frac{q_{1}}{C_{p} \rho} \cdot H_{1}}{V_{* 1}{ }^{3}}=\frac{k \frac{g}{\Theta_{0}} \cdot \frac{q_{2}}{C_{p} \rho} \cdot H_{2}}{V_{* 2}{ }^{3}}
$$

となり, 両辺の $g, \theta_{0}, C_{p}, \rho$ はほぼ共通であるとみな せるから

$$
\frac{q_{1} H_{1}}{V_{* 1}{ }^{3}}=\frac{q_{2} \frac{H_{2}}{V_{* 2}{ }^{3}}}{{ }^{2}}
$$

が得られる。この関係が $(H / L)$ を相似にさせるための 条件である。

$U_{1}$ と $U_{2}$ とを一致させない場合, $q_{1}$ と $q_{2}$ とを一致さ せれば

$$
\frac{V_{* 1}{ }^{3}}{H_{1}}=\frac{V_{* 2}{ }^{3}}{H_{2}}
$$

特に実際の現象に括ける $H_{1}$ の高さの風速と模型実験 に怙ける $H_{2}$ の高さの風速とを等しくすれば $V_{* 1}=V_{* 2}$ とみなせるから，上式は

$$
q_{1} H_{1}=q_{2} H_{2}
$$

となる。この結果は

$$
\frac{H_{1}}{H_{2}}=\frac{q_{2}}{q_{1}}=\sigma
$$

と書きかえられ, 実物の大きさが模型の $\sigma$ 倍ならば, 模 型実験で必要とされる輸送熱量の大きさは実際の現象で 起つている輸送熱量の $\sigma$ 倍でなければならないことを意 味して和り，一般に小さな模型を使り風洞実験では大き な熱量が輸送されるように模型の地表面を強く加熱ある いは冷却してやることを必要とすることが判る。一例と して $1 / 100$ 模型を考えるならば, 輸送熱量は 100 倍でな ければならず, 普通に起る $\pm 0.1 \mathrm{cal} / \mathrm{cm}^{2} \mathrm{~min}$ 程度の輸 送熱量を伴う自然風現象を風洞で再現するためには 10 $\mathrm{cal} / \mathrm{cm}^{2} \mathrm{~min}$ 程度の熱輸送が起るよ 5 に模型の地表面を 人工的に加熱したり冷却したりしなければならないこと になる。

またもし $q_{1}$ と $q_{2}$ を著しく相違させることが困難であ るような場合には， $V_{*}$ を調節することによつて (3.9) の関係を満足させる方法を考えなければならない。これ は

$$
\frac{V_{* 1}{ }^{3}}{V_{* 2}{ }^{3}}=\frac{q_{1} H_{1}}{q_{2} H_{2}}
$$

という関係で表わせるように， $q_{1} \approx q_{2}$ ならば

$$
\frac{V_{* 1}}{V_{* 2}} \approx\left(\frac{H_{1}}{H_{2}}\right)^{1 / 3}=\sigma^{1 / 3}
$$

となることが要求される。従つて $\sigma$ がせいぜい 10 程度 の值ならば， $\sigma$ 分の 1 の模型で実物と同様な輸送熱量 $q_{1} \approx q_{2}$ が存在する場合には実際の現象の高さ $H_{1}$ におけ る風速の約 2 分の 1 の風速を模型に和ける高さ $H_{2}$ に生 ぜさせればよいことになる。この結果は小さな現象では 安定度の効果が小さな風速で現われ易いことを意味する ものと解釈される。

安定度による影響が最も顕著にあらわれる日常現象の 一つは煙突の煙の拡散である。そして煙突からの煙の拡 散現象をしらべるためにしばしば風洞模型実験が行なわ れているが，この模型実験に安定度の効果を入れるため にはぜひとも上記の相似法則の採用が必要である。また こうした安定度効果による拡散領域の増減は必然的に防 風垣の防風効果範囲にも変化を生じさせることが予想さ れる。例兄ば不安定な気層の中では防風垣の吸收する負 の運動量の拡散領域が広い角度をるつこととなり，それ に応じて垣の後方に打ける風速低下領域が短かくなるこ とになろう。また安定状態ではその逆の現象の起ること が容易に想像される。特に後者の現象は夜間冷却の強い 気層の中での防霜林の模型実験などには特に考慮されね ばならない。

\section{4. 結 び}

中立状態について求められている自然風現象の風洞模 型実験の相似法則が拡散現象の相似条件に他ならないこ とから, 非中立状態に扣ける拡散現象の特徴をつかつて 相似法則の拡張をはかつてみた。得られた結果は従来の 相似法則に更に安定度の効果を表わす項を追加する必要 性を明らかにして拉り，模型実験を行う際に必要となる 地表面の人工的な加熱や冷却の程度を与える関係が求め られた。簡単に言えば小さな模型を使う場合には実際よ りも多くの熱量が表面から, あるいは表面に向つて輸送 されるよらにしなければならないということである。

しかしこの結論は全く思考実験によつて導かれたもの であり，実験によつて験証されることを著者は期待して いる。

\section{引用 文 献}

今井 功 (1958)：科学, 28, 110 .

Inoue, E. (1951) : Geophys. Mag., 23, 1.

井上栄一 (1952)：農技研報告 A 2 号, 1 .

- (1956) : 農業気象, 11, 147.

井上・谷・今井 (1955)：農業気象, 11, 44. 根本 茂 (1958) : 気象学会乱流分科会汇て講演.

Sheppard, P. A. (1958) : QJRMS, 84, 205.

Sherlock, R. H. and Lesher, E. J. (1954) : Air Repair, 4, no. 2, 1.

谷 信輝（1958）：農技研報告 A 6 号, 1 .

Taylor, G. I. (1921)： Proc. London Math, Soc., 20, 196. 


\section{Summary}

Taking the effect on the turbulent structure in atmospheric surface layer of the stability length $L$ defined by Monin and Obukhov (1954) as

$$
L=-\frac{V_{*}^{3}}{k \frac{g}{\Theta_{0}} \frac{q}{C_{p} \rho}}
$$

into account, the vertically two-dimensional phenomena in the surface layer are characterized by the roughness parameter $\left(H / Z_{0}\right)$ and the stability parameter $(H / L)$, where $H$ and $Z_{0}$ denote the characteristic vertical scale of phenomena and the roughness length. The similarity of phenomena is shown to be given by the equality of both parameters of $\left(H / Z_{0}\right)$ and $(H / L)$. The former condition is satisfied by the geometrical similarity of model and the latter requires the condition of

$$
\frac{V_{* 1}{ }^{3}}{q_{1} H_{1}}=\frac{V_{* 2}{ }^{3}}{q_{2} H_{2}}
$$

where sufices 1 and 2 denote respectively the quantities in the actual phenomena and in the model experiment. For example, when the condition of $V_{* 1}=V_{* 2}$ is satisfied by choosing the same wind velocity $U_{1}=U_{2}$ at the heights of $H_{1}$ and $H_{2}$, the heat flux $q_{2}$ must be incresed to $\sigma$ times $q_{1}$, where $\sigma$ is the reduction rate of model scale, i.e. $\sigma=H_{1} / H_{2}$. Several methods are proposed of appling these theoretical considerations to the model experiments of the stack meteorology and of the wind break problems in a strongly stabilized surface layer during winter cold nights when the frost damage to vegetations is apt to break out.

\section{軎 評}

\section{褕藤錬三編 全国農作物栽培分布図説}

農業気候の研究には丒論, 農学地理, 農業生態の研究 を行うには，先ず農作物の正確な地理的分布を知ること が必要である。ところが我国の各種農作物について国内 の詳しい裁培分布を知るには, 自から統計書をひるとく ほかはなかつた。しかし手軽るに入手できる統計書には ごく主要な作物について, しかも多くの場合県単位に記 載されているにすぎないので, 少し立入つた調查には余 り役立たない。

この度気象庁の斉藤・荒井両氏編による全国農作物栽 培分布図説は，この点をある程度満たしてくれるものと してありがたい。本書は 1950 年の世界農業センサスの 資料に基ずいて, 我国の重要と思われる 75 種類の農作 物の栽培分布図を市郡別に描いたものである。単に分布 図だけでなく75種類の農作物について，それぞれ名称， 性状, 由来, 分布, 用途, 栽培を記述し, 写真と共に5 まく一頁にまとめてある。これだけの農作物についての 上記の記載は農作物についての事典的役割もはたしてく れて便利である。また最後に農業気候図括よび表をかか げてある。これまで多数の気候図表があるが，直接農業 に利用しにくい欠点があつたが，ここには農業に必要な ものにしぼつてまとめてあるのが特徵である。

本書には以上の如くこれまでにない新しい意図がもら
れ, 農業気候や農業地理の研究を行らのに便利なのみな らず, 日本の農業, 農作物についての一般的知識をうる のに好都合な本といえょう。従つて農業技術者や農政担 当者が常時座右に置いて事典的役目に使用して便であ り，農業高校の先生方の教授資料として活用できるもの として推せんできよ5。

ただ本分布図が 1950 年（昭和 25 年）の資料に基ず いているため，やや古い感がなくもない。作物によって はかなりこの数年間で変化したものがあるからである。 その久を補 5 意味で昭和 31 年度の県別の作付面積表を かかげているが，1960年には再び世界センサスが行われ るので，その機会に是非改訂されることを希望したい。 またこの分布図がどの作物についても一律に市郡別収穫 面積 100 町歩以上, $99 \sim 10$ 町歩, 10 町歩未满の 3 段階 に区分されている点が気になる。このため図がやや平面 的な印象を与光，作物によつてはどこが適地であるのか 知りにくいこともある。この久も県別の作付面積表で補 なら考えのょうであるが，今少し工夫が欲しかつたと思 ら。な怙市別の境界を印刷した透明セルロイド板を付け て扣いてもらうと，利用上便利なように思う。（坪井八 十二)

一一東京堂, 34 年 5 月 11 日初版 188 頁, 550 円— 